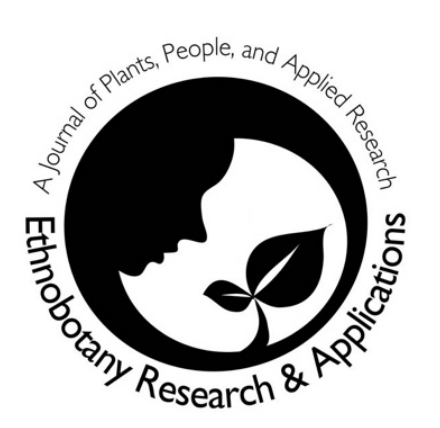

\section{The ethnobotanical} character of the Polish Dictionary of Folk Stereotypes and Symbols

Olga Kielak

\section{Research}

\begin{abstract}
Background: The aim of the article is to present the ethnolinguistic methodology used by a team of Lublin-based ethnolinguists centered around Jerzy Bartmiński, the originator and editor of Słownik stereotypów i symboli ludowych [Dictionary of Folk Stereotypes and Symbols], which has been published since the 1980s, and to demonstrate the ethnobotanic character of the second volume of the Lublin ethnolinguistic dictionary. By outlining the areas common to ethnobotany and ethnolinguistics, the article hopes to pave a way for a satisfactory cooperation between the representatives of both fields.
\end{abstract}

Methods: Using the methodology applied in the abovementioned ethnolinguistic dictionary, in particular the cognitive definition method, the author reconstructs the dictionary entry mirt 'myrtle' (Myrtus communis). On the basis of the collected source material (lexicographic, folklore and ethnographic data), the following semantic subcategories in the cognitive definition of the myrtle are distinguished: complexes, collections and equivalents; appearance and properties; location; cultivation and care; practical, ritualistic, magical and medicinal applications; prophecies; fortune-telling and symbolism, which follow the analysis of names and ways of categorising plants, according to the postulate of the subjective reconstruction of the linguistic worldview.

Results: The author presents a tabular compilation of selected semantic subcategories, which are used in Słownik stereotypów $i$ symboli ludowych to describe plants and explains how they are understood. As a result, the proposed facets can inspire other similar research in Europe or worldwide.
Conclusion: On the basis of the conducted analyses, the author comes to the conclusion that the issues described in particular facets, which constitute the ethnolinguistic narrative about plants largely coincide with the area of interest of ethnobotany. The commonalities between both disciplines include: the object of research, the relations between the plant world and the human world described in both disciplines, the appreciation of the role of language and the subjective view of the world. The reflections presented in this article indicate the possibility of future interdisciplinary research, bringing together linguists and botanists.

Keywords: ethnolinguistics, ethnobotany, cognitive definition, linguistic worldview

\section{Correspondence}

\section{Olga Kielak}

Department of Polish Studies, Maria CurieSkłodowska University in Lublin, PI. Marii CurieSkłodowskiej 5, 20-031 Lublin, Poland 129

"Corresponding Author: olga.kielak@poczta.umcs.lublin.pl

\section{Ethnobotany Research \& Applications} 19:42 (2020)

\section{Background \\ The most recent encyclopaedic definitions of ethnobotany describe it in the following way: \\ Ethnobotany is the study of human-plant interactions in their historical and geographical totality. Important questions include how plants are perceived, named, classified, and used; how their interactions with other species are understood; and the symbolic and material aspects of their management, harvesting,}


processing, and use. Studies have often prioritized the cognitive, linguistically encoded, and thus easierto-elicit and easier-to-systematize aspects of knowledge, usually within such specific domains as health, nutrition, agriculture, or resource management, and in local contexts (Alexiades 2018).

This field of research, which aims to study cultural knowledge of biological resources, rapidly developing in the Americas, many parts of Africa, Asia, Oceania and Europe (Alexiades 2018), has much in common with research undertaken in the $19^{\text {th }}$ century by Polish ethnographers, as it was repeatedly pointed out by Polish scholars (Klepacki 2007; Köhler 2014; Łuczaj 2014). "Images, beliefs and tales about the plant world" (Rokossowska 1889), "a collection of superstitions about plants" (Rostafiński 1895), "people's popular views of nature" (Cercha 1904) - these were the terms used by Polish ethnographers in the late $19^{\text {th }}$ and early $20^{\text {th }}$ centuries who published articles on folk knowledge about the origin of plants, their use in folk human and veterinary medicine, in beliefs and rituals related to annual and family rituals, in agrarian, protective and matrimonial magic, in folk fortune-telling customs and prophecies. Their investigations were similar to those undertaken at the turn of the $19^{\text {th }}$ and $20^{\text {th }}$ century by other European researchers from the circle of "folk botany", who are today recognised as the pioneers of European ethnobiology, including: German botanist Heinrich Marzell, Danish ethnobiologist Vagn J. Brøndegaard, French folklorist Eugène Rolland and Norwegian botanist Ove Arbo Høeg (Svanberg, Łuczaj 2014).

Although the name ethnobotany, proposed by the American botanist John W. Harshberger (1896), appeared in the scientific circulation as early as at the end of the $19^{\text {th }}$ century, the term itself began to appear in Polish scientific literature only in the second half of the $20^{\text {th }}$ century. However, the first Polish study in the field of ethnobotany, prepared in accordance with the principles of ethnobotanic research, should not - as some authors would like to see it (Kowalska-Lewicka 1964) - be the book by Maria Henslowa (1962) devoted to selected wild growing plants in folk culture, but the study on the history of cultivated plants and the history of Polish plant names, conducted from the 1880 s by Józef Rostafiński (1888, 1911, 1916), and above all his questionnaire. Based on a survey, published in several Polish ethnographic journals, Rostafiński collected a rich material on the folk names of plants, the methods and history of their cultivation, the spread of particular species, and the related customs and beliefs (Köhler 1993, 2014; Łuczaj, Köhler 2011). Although the botanist himself did not describe his research as "ethnobotanic", today he is considered to be the precursor of Polish ethnobotany (Köhler 2014). Writing about the beginnings of Polish ethnobotany, we should also mention Józef Gajek who was an ethnographer and the editor of Polski atlas etnograficzny [Polish Ethnographic Atlas] (Gajek 1946, 1974, 1981), in which many ethnobotanic phenomena were mapped for the first time in Poland, and which today is considered one of the most fascinating and pioneering projects in European ethnobotany (Łuczaj 2014).

In recent times, Polish ethnobotany has been developing rapidly, as evidenced by the initiatives undertaken in recent years, including the establishment of the journal "Etnobiologia Polska" in 2011, devoted to ethnobotanics, ethnozoology and ethnomycology, as well as numerous conferences and articles by Polish researchers, published in prestigious international journals. As the many achievements of Polish ethnobotany have already been the subject of scientific reflection (Klepacki 2007; Łuczaj 2013), in this article I will only mention a few works in the field of ethnobotany and ethnomycology, published in recent years by Łukasz Łuczaj, Piotr Köhler, Piotr Klepacki, Monika Kujawska and Joanna Typek (Köhler 1993, 2014, 2018; Łuczaj 2011; Kujawska, Łuczaj, Typek 2015; Kujawska, Klepacki, Łuczaj 2017).

After reading Polish ethnobotanical studies - which provide knowledge on how people incorporate plants into their world and how they assign them symbolic meanings - an anthropologically oriented linguist comes to the conclusion that ethnographers, botanists, pharmacologists and ethnolinguists talk, to a large extent, about the same thing, but use different scientific apparatus and in their analyses they emphasise different aspects of the same phenomena. By introducing the methodology adopted by ethnolinguists in their description of plants, in this article I want to indicate some areas common to ethnobotany and ethnolinguistics, which - at least in my view - open the way to mutually satisfactory cooperation.

\section{Materials and Methods}

In the dictionaries of Polish, ethnolinguistics (Greek ethnos 'people', 'tribe', 'nation', Latin lingua 'language') is defined as a subfield of linguistics which studies the relationships between language and culture. Focusing on "culture in language", the aim of ethnolinguistics - according to Jerzy Bartmiński - is to "subjectively reconstruct the worldview" preserved in language, to examine the linguistic conceptualisation of the world (i.e. the ways of organising the cognitive content in language) and the cultural aspects of grammatical rules, sentence 
and text syntax (Bartmiński 2002). Adopting such a research perspective on language allows the researcher to capture the human understanding of the world.

Bartmiński's ethnolinguistic research programme, which found practical application in Słownik stereotypów i symboli ludowych [Dictionary of Folk Stereotypes and Symbols] published since the 1970s, was inspired by German and American anthropological linguistics (Wilhelm von Humboldt, Edward Sapir, Benjamin Lee Whorf), Bronisław Malinowski's ethnographic approach, Anna Wierzbicka's semantics, the works of Russian semanticists, dialectologists and ethnolinguists (Yuri Apresjan, Vladimir N. Toporov, Nikita I. Tolstoy), and the publications of Polish dialectologists and folklorists (Kazimierz Moszyński, Bernard Sychta and Hanna Popowska-Taborska).

In the course of half a century, besides the experimental Zeszyt próbny Słownika ludowych stereotypów językowych [Trial Issue of Dictionary of Folk Linguistic Stereotypes] (Bartmiński 1980) four issues (out of seven planned) of the first part devoted to the cosmos (Part 1: Niebo, światła niebieskie, ogień, kamienie [Heaven, Celestial Bodies, Fire, Stones] - 1996; Part 2: Ziemia, woda, podziemie [Earth, Water, Underworld] - 1999; Part 3: Meteorologia [Meteorology] - 2012; Part 4: Świat, światło, metale [World, Light, Metals] - 2012) (SSiSL) and four issues devoted to plants (described in detail below) were published.

The aim of the dictionary is to reconstruct - using the methods adopted from ethnolinguistics and folklore studies - the traditional view of the world and the human based on stereotypes and symbols, which is then the key to learn a culture, a certain attitude towards the world and a specific mentality characteristic of that culture (Bartmiński 1996). The Lublin ethnolinguistic dictionary proposes an interdisciplinary approach, using a linguistic apparatus to analyse folklore texts (Bartmiński 1996).

The methodology used in the dictionary should be situated in the cognitive ethnolinguistics paradigm (Tabakowska 2001, 2013; Zinken 2009; Głaz 2013). According to the methodological assumptions of Słownik stereotypów i symboli ludowych (henceforth SSiSL) (Bartmiński 1980, 1996, 2005, 2006, 2007, 2009, 2011a, 2016), individual images are reconstructed using the method proposed by $\mathrm{J}$. Bartmiński, i.e. based on the cognitive definition, "the main goal of which is to capture the way the object is understood by the speakers of a given language, i.e. the way that is socially entrenched, derives from the knowledge about the world, the categorisation of its phenomena, their characteristics and evaluation, all of which can be accessed through language and language use" (Bartmiński 1988).

The authors of individual dictionary entries arrange the stereotypical judgements creating the images based on the conjunction of features into semantic subcategories, called facets, which can be distinguished from the gathered material. The quintessence of the entry is the "capsule"- the most important, most strongly entrenched characteristics of the defined object. The "capsule" is usually followed by a general cultural introduction, which enables the confrontation of Polish images of the defined objects with their images present in other cultures of the world. The main part of the description is the explication, reconstructed on the basis of the gathered documentation, and the documentation part, organised according to the genre, including numerous texts of folklore, often in many variants.

Ethnolinguistics, practiced by the group of linguists centred around J. Bartmiński, puts language in the foreground (systemic data and texts as manifestations of the linguistic system), but it is directly followed by beliefs and practices that allow the researchers to place linguistic data in a wider cultural context. This significant shift in the boundaries of linguistic description, criticised by some linguists, e.g. Maciej Grochowski (1993), is one of the hallmarks of the Lublin school of ethnolinguistics. It favours a holistic dictionary description (Niebrzegowska-Bartmińska 2014), i.e. a joint analysis of linguistic, textual and "paralinguistic" data (folk beliefs and practices) that constitute a single entity both from the scientific perspective and in the images of the folk culture carriers (Tołstoj 1992).

Consequently, the authors use three types of data as a material basis: (a) lexicographic data extracted from dictionaries of Polish, dictionaries of phraseological expressions, dictionaries of synonyms and antonyms, dictionaries and atlases of dialects, and etymological dictionaries; (b) folkloristic data, i.e. different text genres, starting with the socalled "small forms" such as riddles, proverbs, weather forecasts, through forms of magical poetry: enchantments and spells, rhymes and nursery rhymes, prayers; arranged in the following order: ritual folk songs (annual and family), texts of dialogues, shows and speeches (New Year's and wedding speeches), fairy tales, cosmogonic myths and aetiologic tales, tales and legends, anecdotes, beliefs and memoirs, popular tales and written peasant poetry; and (c) ethnographic data, i.e. records of beliefs and descriptions of practices, 
including both the materials recorded from $18^{\text {th }}, 19^{\text {th }}$ and $20^{\text {th }}$-century ethnographic sources and those recorded in recent years by members of the ethnolinguistic team.

Individual descriptions employ a comprehensive panchronic approach, which - as opposed to synchronic and diachronic approaches - abolishes time divisions and allows for the presentation of certain generalised characteristics (Łozowski 1999).

The second volume of SSiSL, published in Lublin and devoted to plants, can certainly be described as an ethnobotanical study. So far, four issues describing the world of plants have been published: Zboża [Cereals] (2017); Warzywa, przyprawy, rośliny przemysłowe [Vegetables, Spices, Industrial Plants] (2018); Kwiaty [Flowers] (2019); and Zioła [Herbs] (2019). The next four, dedicated to bushes and shrubs, trees, plant clusters, weeds and mushrooms, are in preparation. The declaration concerning the proposed units of description was published in the introduction to the first issue in the plant series:

Describing the field of plants, in our Dictionary we follow the lead of anthropologically oriented linguists, we ask about the traditional peasant - or more broadly - the folk image of the plant world, about the folk conceptualisation of this world. It simultaneously has a realistic and mythological character. Cereals and vegetables are the most important of all plants for rural, agricultural communities, because they serve to satisfy basic human needs in life; further, there are herbs and flowers, shrubs and trees, and on the peripheries of the semantic field there are mushrooms and weeds. The subjects of the particular issues in the volume Plants are arranged in this order (Bartmiński 2017).

\section{Results and Discussion}

Ethnobotany in ethnolinguistics or a cognitive description of plants

In order to demonstrate the ethnobotanical character of the second volume of the Lublin ethnolinguistic dictionary, the entry 'mirt' [myrtle] (Myrtus communis) will be presented below as one of the entries from the lexical field "shrubs", reconstructed by the author of this article using the cognitive definition method. The presented entry consists of the "capsule", the general cultural introduction and the explication.

On the basis of the collected source material, the cognitive definition of myrtle consists of such semantic subcategories as complexes, collections and equivalents; appearance and properties; location; cultivation and care; practical, ritualistic, magic and medicinal applications; prophecies; fortune-telling and symbolism. These categories were preceded by the analysis of names and methods of plant categorisation, in accordance with the postulate of the subjective reconstruction of the linguistic worldview. The explication of the myrtle will allow the readers to learn about the "content" of the particular facets which are distinguished in the dictionary while describing plants. Although the individual entries in SSiSL are composed of two parts: the explication and the documentation, connected by a network of numerical references which enable the verification of the properties referred to in the explication, for the purposes of this article, the two parts have been merged - fragments of texts appear directly in the explication.

\section{The linguistic and cultural worldview of the myrtle (Myrtus communis)}

The myrtle, a small bush or a potted plant with green leaves and white flowers, used to be grown in homes inhabited by girls and in home gardens; the cultivation and nurturing of the myrtle was the responsibility of a maiden until her marriage. In some regions of Poland, girls were told that they would marry soon or late based on the "good growth" of their plant; at the same time, it was believed that a disaster would happen and the girl would become a spinster where the myrtle grew (bloomed).

In the Polish countryside, the myrtle was widely used in family rituals (christening, wedding and funeral) and annual rituals; it also appeared during Catholic ceremonies, such as First Communion or first masses. In traditional culture, the plant symbolises purity and innocence, and for this reason it was used to adorn newlyweds and people that died prematurely, children brought to baptism or First Communion, and newly ordained priests as pure and innocent persons. The maidenliness, virginity and youth associated with the myrtle appear in the lyrics of folk songs, e.g. when a girl asks a boy nie połamat jej grzędy $u$ lawendy [not to break her perch of lavender] and nie podeptał mirty [not to trample on her myrtle], she wants him to respect her virginity.

In Mediterranean cultures, the myrtle was a symbol of the regeneration of vitality, fertility, love and sex; it was associated with the Babylonian goddess Ishtar, Greek Aphrodite, Roman Venus/Venera; it was also dedicated to Demeter, Apollo and also, because of its connection to death, to Hades. The evergreen myrtle was a symbol of immortality. Already in ancient times, myrtle leaves emitted a pleasant smell and were used to make essential oil for medicinal purposes, while myrtle berries were used to make wine (Kopaliński 1985; Forstner 1990; Kowalski 1998). 
The myrtle was used to make wreaths, which in IndoEuropean cultures played an apotropaic role, allowing for the transition from the ritual phase of death to a new form and new status, hence they were put on the heads of the newlyweds and the deceased (Bächtold-Stäubli 1927-1941; Kowalski 1998).

In ancient Persia and in the Middle East, the myrtle was regarded as a symbol of immortality and vitality, it was dedicated to the goddess of love and war, Ishtar. It was used by the ancient Assyrians to treat eczema, wounds and ulcers. In Turkey and India, powdered myrtle leaves were used to treat open wounds (Dafni 2016). From the ancient times, the myrtle had been considered the most important "wedding plant" in all religions of the Ancient East and Mediterranean (Dafni et al. 2019).

In Africa, the myrtle was regarded as a symbol of eternity, it was used in funeral rites (Dafni 2016; Dafni et al. 2019).

The Babylonian Talmud refers to paradise as a "garden of myrtle" (Dafni et al. 2019); Muslims believed that myrtle sprigs are given to people before the gates of Paradise; the myrtle smells of paradise, while Muhammad's sword was made from myrtle leaves growing in paradise and brought to the earth by Adam (Dafni 2016; Dafni et al. 2019).

Ancient Greeks and Romans saw the myrtle as a symbol of virgin charm, and thus dedicated the plant to the goddess of beauty and love, Aphrodite (Venus). In Greek mythology, the myrtle, the plant of Aphrodite, was the first costume of the goddess when she hid behind the myrtle bush. This plant was usually planted around the temple of the goddess, and the initiated participants of the cult of Aphrodite wore myrtle wreaths on their heads. Since the myrtle is an evergreen plant and it was also dedicated to Persephone, the goddess of the underground world, this plant appeared in ceremonies connected with funeral rituals, e.g. the myrtle and marjoram were used to decorate funeral beds, graves were decorated with myrtle. In ancient Greece, as a sign of love and engagement, the maidens used to wear myrtle wreaths on their heads, they were also put on the heads of young spouses. The myrtle, which for the ancient Greeks was initially a symbol of love (white blooming myrtle - a symbol of peace, decency and virgin beauty), later became a symbol of slavery and a tombstone plant (Bächtold-Stäubli 1927-1941; Forstner 1990; Kowalski 1998; Dafni 2016).

Also in ancient Rome, the myrtle was a symbol of peace and was connected with the sphere of death Roman legions, returning from the expedition, on which they managed not to shed too much blood (and not to defile themselves through contact with death), decorated themselves with myrtle sprigs or myrtle wreaths. The Roman historian Pliny wrote that the drink of myrtle purifies the bile - for this reason, serving it after the Sabine women were kidnapped calmed down the agitated minds and led to the reconciliation of the disputed parties. Ancient Greeks and Romans were familiar with myrtle wreaths. Plutarch mentioned the custom of decorating heads with myrtle wreaths during cheerful feasts, as they were the sign of joy; on similar occasions a myrtle sprig was carried among the feast participants to encourage them to sing - the person who began singing or sang solo, took the myrtle sprig in their hand and walked with it around the feast participants. In ancient Greece and Rome, myrtle (or olive) wreaths were placed on the head of the deceased, and the mourners participating in the funeral rites decorated their heads with them. These wreaths "guaranteed the dead peace in the grave, and for the living they served a defensive function, helping the suffering persons to come to terms with their fate" (Forstner 1990; Kowalski 1998).

In the Old Testament, myrtle sprigs appear (next to other sprigs) during the Jewish Feast of Tabernacles, commemorating the regaining of freedom by the Israelites. At that time, woven myrtle wreaths were used as home decoration; these wreaths not only symbolised the festive circumstances, but also protected against unwanted encounters with demons. In the books of the Old Testament, the myrtle is a sign of joy; it is supposed to represent the Israeli people who remained faithful to God. In the Book of Isaiah, the myrtle is mentioned among the trees of the Messiah's garden of pleasure, which is to blossom in the desert and among thorny bushes; in the Book of Zechariah, the angel of the Lord announces to Zechariah the joyful news of the restoration of Jerusalem and the temple among the myrtles in the valley. In the Jewish tradition, myrtle wreaths adorned the heads of the newlyweds. The name of Queen Esther (Hadassah), a beautiful, graceful and chaste virgin saviour of Israel, derives from hadas 'myrtle', and in Assyrian the word hadasatu means fiancée (Bächtold-Stäubli 1927-1941; Forstner 1990; Kowalski 1998; Dafni 2016).

In the Christian culture, the myrtle, one of the signs of virginity, is associated with the Mother of God; according to St. Gregory, the myrtle symbolises moderation and self-control, and compassion for others' misfortune (Forstner 1990; Kowalski 1998).

In the Germanic tradition, the myrtle is associated with youth and innocence. Referred to as the "tree of life", it was planted at the birth of a child. It was 
believed that the myrtle, from which a sprig is cut for strangers or a sprig/flower is cut for a wreath for the dead, withers; by contrast, it grows when sprigs or flowers are cut for a wedding wreath, which, however, should not be worn by a bride who has an illegitimate child. Ancient Germans believed that a girl should not cultivate the myrtle because, as they used to say: Kto uprawia mirt, nie będzie nigdy panną młodą [Whoever grows the myrtle will never become a bride], Gdzie mirt dobrze się rozwija, tam nie będzie umizgów [Where the myrtle is growing well, there will be no courtship]. It was commonly believed that if the myrtle was blooming, its owner would not get married that year. It was believed that a gift of myrtle to a virgin would cause her to remain unmarried; the quick withering of myrtle bushes given to the engaged couple was also considered a bad sign. The myrtle, associated with youth, was also involved in matrimonial fortune-telling. On Christmas Eve, myrtle leaves were put on the water and given the names of maidens and bachelors; it was believed that if the leaves came together, the respective persons would get married. In the Germanic tradition, the myrtle also appears in funeral rituals. It was believed that the blooming of the myrtle heralds the death of one of the household members. During the funeral, the attendees used a myrtle bouquet as an aspergillum to sprinkle the deceased with holy water. The myrtle sprigs, used during the funeral of the young deceased, should be put back into the ground, because it was believed that they would continue to grow. The myrtle was also used in folk medicine. It was believed that tea of myrtle leaves from the wedding wreath is an effective cure for every disease; three leaves of myrtle from the bride's wreath were supposed to effectively combat the fever. It was believed that a toothpick made of myrtle wood would protect against toothache (Bächtold-Stäubli 1927-1941).

\section{Names}

The name mirt [myrtle] (Myrtus communis) - In the national standard language and in dialects of Polish also referred to as myrt (Podgórski, Podgórska 2008), miert (Dejna 1978), mirta (Karłowicz et al. 1952-1953), merta (Karłowicz 1900-1911), mierta (Wronicz 1995), myrta, merda (Karłowicz 19001911), mertyn (Paluch 1988), mertin (Podgórski, Podgórska 2008), mertyna (Śmiełowski 1967), mirtyl (Karłowicz et al. 1952-1953); in the folk Polish language, mainly in folk songs, in diminutive form: mirtka, mertka, mirteńka, mirteczka (Rogowska 1998), miyrcik (Kąś 2015-2018) - originates from Latin myrtus < Greek mýrtos (Bańkowski 2000). In the lyrics of songs from the Ostróda-WarmińskoMazurskie region, the myrtle is also called ruta, rutka, ruteczka (Dubisz 1977).

\section{Categorisations}

In dictionaries of Polish (including dialect dictionaries), the myrtle is defined as krzew [shrub], krzak [bush]. Grown in pots on windowsills and in home gardens, it is classified as a flower, potted flower or (ornamental) potted plant. Other, less common names of myrtle, carrying a categorising segment, are: mirtowe drzewo [myrtle tree] (Karłowicz et al. 1952-1953), in Orava - kalwaryjskie ziele [Calvary herb] (Kąś 2011).

\section{Complexes, collections and equivalents}

In wedding speeches and songs, the myrtle is most frequently combined (and sometimes interchangeable) with flowers and herbs associated with maidenliness and virginity, among others, with rosemary (Rosmarinus), cf. the bride catches a wreath which fell into the well with her right hand, from the wreath there come out $d$ wie równianki mirtu $i$ dwie rozmaranu [two sprigs of myrtle and two of rosemary] (Bartmiński 2011b); with lavender (Lavandula), cf. the girl asks the boy nie połamat jej grzędy u lawendy [not to break her perch of lavender] and nie podeptał mirty [not to trample on her myrtle], i.e. asks him to respect her virginity (Kolberg 1969); with fuchsia (Fuchsia), cf. the bachelor's fears that smędzące na Śląsku kominy zasmędzą okienko, merty i fuksyje, z czego moja dzioucha wiynuszek uwije? [the smoky chimneys in Silesia will make the window, myrtle and fuchsia dirty, how will my girlfriend be able to make a wreath?] (Dygacz 1987); or with the rue which - similarly to the myrtle - in songs is sown by a maid who wants to get married (Hrycyna 2019).

\section{Appearance and properties}

The myrtle has glossy, dark green leaves (Szymańska 1991), it belongs to evergreen plants (Drabik 1990), hence the folklore texts refer to zielony mirt [green myrtle] (Bartmiński 2011b; Szymańska 2012). Due to its small leaves, in the lyrics of folk songs it is characterised as small, e.g. Mój wianeczek jest zielony, z drobnej mirty uwiniony [My little wreath is green, made of small myrtle] (Bystron 1927). Myrtle leaves are delicate and when dried, they crumble easily, thus in a wedding song the bride asks before the blessing: Rozścielaj, mamo, obrusy pod nogi dla córki swej, niech z wieńca mirt sie nie kruszy, który upletli jej [Mother, spread tablecloths under the feet for your daughter so that the myrtle does not crumble from the wreath which has been woven for her] (Bartmiński 2011b).

The myrtle blooms with white flowers, which is recorded in a wedding song from the Lublin region: Stoi mirta w oknie, białe kwiaty puszcza, dziś nasza Marysia panienstwo opuszcza [There is myrtle in the 
window, it has white flowers, today our Mary leaves the maidenhood] (Bartmiński 2011b).

The leaves of the plant, rubbed between fingers, emit a pleasant smell, which is recorded in wedding songs in which the myrtle is the fragrant miyrcik $z$ wianeczka panny młodej [myrtle from the bride's wreath], the smell of which reached the participants of the wedding (Jasiennik Stary 1977). Because of the characteristic smell of myrtle, it was occasionally used as incense for a deceased person "so that there would not be the smell from the deceased" (Paluch 1985), see the ritualistic applications.

\section{Location}

The myrtle was grown as an ornamental plant in pots on windowsills, cf. in the song stoi mirta w oknie [there stands a myrtle in the window] (Bartmiński 2011b), and in home gardens (Kolberg 1883/1962).

\section{Cultivation and care}

The myrtle was grown in homes where there were girls (Udziela 1890), it was used for przyjęciny, i.e. for First Communion (Łęga 1933) or weddings. Usually it was the task of the maiden to grow and care for this plant "until she got married" (Łęga 1933), for a wedding wreath (Burszta 1967), hence in wedding songs the maiden drobno sieje [thinly sows] the myrtle (Płatek 1976) and podlewa go rosa [waters it with dew] (Janicka-Krzywda 2001).

In Wielkopolska region, on the occasion of each child's birthday, a myrtle pot was planted, because it was believed that każde dziecko powinno mieć swoją mertę [each child should have its own myrtle]. Before the wedding, the bride was made a wreath from the myrtle planted especially for her, and from the bachelor's myrtle a sprig was cut off for the wedding ribbon for the groom (Burszta 1967). It was believed that the best growing myrtle is that planted from a sprig which had previously been used to decorate the outfit of a bride or a child carried to baptism (Janicka-Krzywda 2001).

In Kujawy region, the "good growth" of the myrtle was used to tell the girl if she would get married soon or late (Szulczewski 1966); in the Lublin region it was said that if a girl is not virtuous, the pot with myrtle would wither (Niedźwiada 1977). At the same time, it was believed that where the myrtle grows (blooms), a disaster would happen and the girl would become a spinster; see prophecies.

The home myrtle sprigs were given out with reluctance in order nie wydawać szczęścia [not to give away good fortune] (Kujawska et. al. 2016). It was believed that giving the myrtle to a bride who does not have this plant herself would "take away the popularity with the opposite sex of the maidens from the donor family" (Janicka-Krzywda 2001). In the Polish-Ukrainian borderland it was believed that jak sie pożyczy takiej, co ona w ciąży je, ten mirt zginie [if you borrow the myrtle for a bouquet to a pregnant woman, this myrtle would wilt] (Wietlin 1988). It was also believed that cutting the myrtle sprigs to decorate the coffin or candles accompanying the deceased, it causes "the whole bushes from which the sprigs originated to wither" (Gaj-Piotrowski 1967).

\section{Practical applications}

In the past, there was famous mirtynek, i.e. wine seasoned with myrtle; cf. also mirtowany 'seasoned with myrtle berries' (Karłowicz et al. 1952-1953). Olejek mirtowy/mirtellowy [myrtle oil] used in medicine was produced from leaves and fruits (Mayenowa, Pepłowski 1982).

\section{Ritualistic applications}

The myrtle was widely used in family rituals (christenings, weddings and funerals) and annual rituals. It also appeared during Catholic ceremonies, e.g. First Communion or first mass.

The clothes of a child carried to the b a p t i s $m$ was decorated with the myrtle (Janicka-Krzywda 2001); it was stuck in a baby's sleeping bag and used to decorate kapka, i.e. a type of white square cape placed on the sleeping bag (Świątkowska 1978; Kąś 2015-2018).

In the old wedding ritual, the myrtle and a myrtle wreath were an attribute of the bride leaving the maidenhood. The myrtle, usually in the form of a wreath adorned the head of the bride (Udziela 1994; Kąs 2015-2018). The myrtle was also used to decorate the veil (Dekowski 1988) and the bride's skirt (Kąś 2015-2018); the bride, who was a widow pinned a myrtle or rosemary sprig on the right side of the wedding cap (Udziela 1994). A myrtle or rosemary sprig was also used to decorate the hat in which the young married woman went to the church on the first Sunday or holiday after the wedding for wywód, i.e. a special blessing for the newly married woman (Udziela 1994).

Posies of myrtle sprigs or flowers, the so-called woniaczki (Podgórski, Podgórska 2008), woven by the bride and bridesmaids on the eve of the wedding, during the so-called wieczór dziewiczy [virgin evening] (Kopczyńska-Jaworska 1989), tied with a white ribbon and fastened to the lapel of their jackets were worn by the groom, who in Kashubia and Kociewie was reminded not to let anyone tear off any fragment of the myrtle posy because then someone could enchant the bride and groom (Nadmorski [Łęgowski] 1892). Such posies were also worn by starosts, matrons of honour, best men and all 
wedding attendants (Reinfuss 1965; Bartmiński 2011b). Sometimes the bride and bridesmaids pinned myrtle posies to men as a sign that they choose them to be their "companions for the entire wedding event" (Ciszewski 1886). The myrtle was also used to adorn the collar of a wedding pytac [asker], matchmaker's hat (Kąś 2015-2018). The myrtle or rosemary adorned a white towel, with which the best man was riding on horseback around the village, inviting people to the wedding (Burszta 1967). Bridesmaids used myrtle to adorn their corsets and bras (Dekowski 1978).

It was also used to decorate other props connected with wedding rituals, e.g. during engagement, a cross standing on the table (Karwicka 1979) and a plate with the rings were decorated with myrtle (Sychta 1967-1976); it was also used to decorate a wedding rod or korovai (Bartmiński 2011b), i.e. a ritual wedding cake; in Podhale - also a chest with a dowry, transported to the bridegroom's house (Kąś 2015-2018).

During oczepiny [unveiling and capping ceremony], the myrtle wreath and myrtle and rosemary sprigs were removed from the bride (Udziela 1994), and the myrtle posy was detached from the groom's jacket (Sobierajski 1960). The myrtle sprigs removed from the bride's head, were taken away from the bridesmaids by matchmakers who thus ensured themselves "good fortune to enter a marriage" (Udziela 1994).

Only "virtuous" newlyweds were entitled to use myrtle decorations. It was believed that przeskoczka, i.e. a "fallen" girl should not have myrtle in her hair or a myrtle wreath on her head (Udziela 1994). Similarly, a groom who already had a child was not eligible for myrtle decoration (Burszta 1967).

As opposed to its common use in wedding rituals, in funeral rituals the myrtle appears almost exclusively during the funeral of children and young people who were not married (Libera, Paluch 1993). On the one hand, its use emphasises their youth and innocence, and on the other hand, as many folklore researchers point out, it makes the funeral a symbolic wedding ritual (Paluch 1985). It was used to adorn the head of deceased girls/maidens (GajPiotrowski 1967; Paluch 1988), sometimes also the heads of bachelors and children (Paluch 1988); children were attached myrtle sprigs to their dresses (Gaj-Piotrowski 1967), maidens and bachelors myrtle ornaments and bouquets (Burszta 1967; GajPiotrowski 1967; Libera, Paluch 1993), "as it is done during a wedding" (Łęga 1933). Myrtle flowers or sprigs decorated the coffin (Gerlich 1984; Libera, Paluch 1993). In Wiry near Poznań, dead maidens were incensed with myrtle (Paluch 1985).
The myrtle and myrtle wreath are also present during other Catholic celebrations, e.g. during the First Communion a myrtle wreath is put on girls' heads (Łęga 1933) and their dresses are decorated with this plant (Libera, Paluch 1993), while boys were tied a myrtle posy to their breasts with a white ribbon (Łęga 1933) or myrtle sprigs were put in the lapel flap of their suit (Lipiński 1965).

Myrtle appears in the first mas s ritual, which culminates in the first solemn mass celebrated by a newly ordained priest. Before leaving the family home for the church, after the blessing, the parents sprinkled the young clergyman with an aspergillum made of myrtle or boxwood sprigs. The young priest himself was dressed in a surplice adorned with myrtle sprigs, and already in the church a myrtle wreath was ceremonially placed on his head (Pyla 2004).

Furthermore, myrtle sprigs were also used to decorate the blessed candle on the Feast of the Purification of the Blessed Virgin Mary (2 February) (Karwicka 1979); the myrtle was added to the Easter palm (Karwicka 1979) and sometimes it was also used to decorate święconka [food blessed in the Easter basket] (Libera, Paluch 1993). Little myrtle sprigs were plaited into the hair by girls walking in a Corpus Christi procession (Szeląg 1934).

\section{Magical applications}

The myrtle, considered by the people to be an aphrodisiac, was used in love magic - it was believed that if a girl managed to put a myrtle (or rosemary) sprig into "a boy's clothing worn on the breast", he "would fell in love with her most passionately" (Burszta 1967).

In the past, myrtle was also used to protect against harmful effects of atmospheric phenomena - it was believed that the bride's wreath made of myrtle protects the house in which it is stored from lightning (Libera, Paluch 1993); in Żurawce (Lublin region), myrtle and periwinkle were used to decorate pine tree crosses, made and put in gates and windows on the eve of St. John the Baptist (23 June) with the intention of protecting against storms and hail (Bartmiński 2011b).

\section{Medicinal applications}

Patients with facial oedema, inflammatory skin lesions, colic and women's diseases were treated with myrtle (Paluch 1988). Myrtle tea was also used in the case of female diseases (Zborowski 1932). The infusion from the dried myrtle sprigs was drunk also in the case of digestive system disorders (Paluch 1988) or pain in the heart area (Libera, 
Paluch 1993), because it was supposed to cure shortness of breath (Kolberg 1876/1963). Myrtle leaves were applied to a sore tooth (Kantor 1907); in the Middle Ages it was recommended to apply them przećiw káżdému boleniu [in every instance of pain] (Mayenowa, Pepłowski 1982). The Masurians believed that myrtle leaves from a wedding wreath were an effective remedy for zimnica [cold], i.e. the fever (Toeppen 1892; Paluch 1988).

\section{Prophecies}

Although it was a common practice to plant myrtle in homes inhabited by maidens, it was believed that where it grows, there was no good fortune (Steuer 1937). In Kraków, the Beskids, Orava and Podhale regions, the blooming myrtle was considered a harbinger of illness, death, and for an unmarried girl it heralded the spinsterhood (Fischer 1921; JanickaKrzywda 2001). It was believed that girls from the cottage where myrtle is cultivated "rarely get married", hence the proverbs: Gdzie się mirty darzą, tam dziewczęta próżno o weselim marzą [Wherever there are myrtles, the girls dream in vain of a marriage] (Sychta 1967-1976).

Fortune-telling The myrtle was widely used in matrimonial fortune-telling. On the eve of St. Andrew's Day (29 November), the maidens released two needles or two leaves of myrtle, symbolising a boy and a girl, into the water in a bowl or a plate. It was believed that when the needles or leaves released on the water come together, it would be a sign of the wedding for the young couple (GajPiotrowski 1967; Pośpiech 1987; Niebrzegowska 2000). Similar fortune-telling took place on Christmas Eve (Pośpiech 1987). In Pilchów, one myrtle leaf was used during the play - if a leaf thrown into the water flowed out in the middle of a dish, it was an auspicious sign; if it drowned, the maiden was to remain unmarried. In Silesia, on St. Lucy's Day (13 December), girls put two leaves of myrtle on the water - one symbolising a bachelor and the other a maiden - it was believed that if a leaf symbolising a bachelor was standing still, and the other was moving towards it, his love was insincere, and vice versa (Kawalec 1929).

St. Andrew's Eve fortune-telling party was popular on the entire Polish territory. During this night, various items, including myrtle, were placed under several plates, bowls or cups. Then the people taking part in the play picked up the dishes and discovered hidden objects; for example, coal was supposed to be a harbinger of mourning in the coming year, bread abundance, salt - tears, a ring - wedding, myrtle was regarded as a sign of imminent engagement, marriage, being the best man, and sometimes even spinsterhood (Knoop 1895; Pośpiech 1987).

\section{Symbolism}

The myrtle is a symbol of purity and innocence, and for this reason it was used as a decorative element with the children for baptism or First Communion, the newlyweds or the persons who died prematurely as pure and innocent people. The myrtle or myrtle wreath is a symbol of the bride's virginity. In the songs, the myrtle symbolises maidenliness, virginity and youthfulness of a girl, e.g. Mirtek hodowała, rosą podlewała. Dziesięć lat minęło, aż się doczekała [She grew the myrtle, watered it with dew. Ten years have passed and finally she achieved it] (JanickaKrzywda 2001); Drobny mirt, drobny mirt, bom go drobno siała, dobry będzie Staszek, bom takiego chciała [Small myrtle, small myrtle, because I sowed it thinly, Staszek will be right, because I wanted such one] (Płatek 1976). When a maiden asks a boy nie podeptał mirty [not to trample on her myrtle], she wants him to respect her virginity, cf.: Mój Jasieniu miły, nie jedźże my tędy, bo byś my połomał $u$ lawendy grzędy. Rzędy mi połomiesz, mirty mi podepcesz; zdradziłeś mnie, łotrze, a teraz mnie nie chcesz [My dear Jasiu, do not go this way or you will break my perches of lavender. You will break my rows, you will trample on my myrtles; you betrayed me, you scoundrel, and you do not want me now] (Kolberg 1969). In wedding songs, the myrtle is as a symbol of permanence and indissolubility of marriage: Pamiyntojcie, państwo młodzi, ze wos nik nie oswobodzi, ze woz już nik nie ozłoncý bez tyn miyrcik, bez pochnioncý [Remember, bride and groom, that nobody will liberate you, that nobody will separate you because of this fragrant myrtle] (Kąś 2015-2018).

As an evergreen plant, the myrtle is a symbol of life and regenerated vital forces, cf. mirt to życie, bo zieluny nawet $w$ zimie [the myrtle is life, because it is green even in the winter] (Pelcowa 2017). For this reason, it appears in rituals associated with the turning points in life, which lead to the regeneration of the person in a new social role (Pyla 2004).

According to the folk dream book, myrtle means spinsterhood, something bad, someone's funeral, death; green myrtle means wedding, something good, child's communion (Burszta 1967; Niebrzegowska 1996).

Similar symbolism applies to the myrtle wreath, which in wedding, flirting, love and family songs is regarded as a symbol of purity and innocence. For this reason it was put on the head of the bride (but only one who kept her purity), the girls who died prematurely, the girls who were going to receive First Communion or the newly ordained priests, as they were pure and innocent people. In SSiSL the myrtle wreath has as a separate entry (Kielak, forthcoming). 
The characteristics of the semantic subcategories used

The individual facets that make up the cognitive definition of the myrtle include the aspects related to naming, cultivation, location as well as practical, ritualistic, magical and medicinal use of the plant; also the role of myrtle in annual and family customs and rituals, and the symbolism of the shrub.

The authors of dictionary entries do not mechanically include the semantic subcategories and their content in the definitions of particular entries, but these semantic categories are reconstructed for each of the described plants in such a way as to bring out the characteristics of a particular plant hidden in the analysed material from the point of view of the carrier and participant of the examined culture (Bartmiński, Niebrzegowska-Bartmińska 2013).

In the case of the hawthorn, the ethnographic records and folklore texts contain information that the hawthorn (Crataegus) was used to make Christ's crown of thorns and, less frequently, the cross. The collected material had to be somehow related to the whole structure of the dictionary entry, hence the proposed facet of "the hawthorn as an instrument of the Lord's Passion", which does not appear with other plants. In the case of the rue (Ruta graveolens) - due to the nature of the collected evidence material - a special subcategory "sowing of rue by maidens" was distinguished. The subcategories identified by the researcher depend on the collected evidence. Therefore, it is not possible to provide a comprehensive list of facets with their semantic content, because they depend on the characteristics of specific plants, and not all plant entries have been developed yet.

Table 1 below presents a preliminary list (work in progress) of selected semantic subcategories, most frequently repeated in plant descriptions, along with their simplified characteristics. A similar list of facets appeared in the experimental Zeszyt próbny Słownika ludowych stereotypów językowych [Trial Issue of Dictionary of Folk Linguistic Stereotypes] (Bartmiński 1980).

\section{Conclusions}

The authors of plant entries published in the Dictionary of Folk Stereotypes and Symbols are not botanists and the reconstructed segments of definitions are not based on botanical facts but - as befits ethnolinguists - on numerous ethnographic and dialectological studies and verbal folklore texts. However, starting from the very first issue of the plant volume, the ethnolinguistic findings have been discussed with a botanical consultant - Dr hab. Robert Gruszecki from the Department of Vegetable Gardening and Herbiculture at the University of Life Sciences in Lublin, so that the dictionary can be used not only by linguists, culture studies specialists, folklorists and ethnologists, but also by botanists, especially ethnobotanists.

The aspects described in the individual semantic subcategories, which combined constitute the ethnolinguistic narrative about plants, largely coincide with the area of interest of ethnobotany they show how humans perceive, name and use plants. Some of the identified semantic subcategories coincide with the semantic domains (functional categories) which were used for the description of plants in another Polish compendium on flora, i.e. in the already mentioned ethnobotanical publication Rośliny w wierzeniach $i$ zwyczajach ludowych. Słownik Adama Fischera (Kujawska et. al. 2016). Its authors divided the use of plants in folklore into the following functional categories: apotropic, economic, cosmetic, medicinal, magical, ritual and ornamental use, food (for hunger, functional, medicinal, ritual), substances, veterinary use, beliefs, children's toys.

Although ethnolinguists do not adopt botanical nomenclature in their description of the world and they prefer cultural over botanical facts, while ethnobotanists rather do not interpret the symbolical meanings given to plants in folk songs, there are many commonalities between ethnobotany and the Lublin school of ethnolinguistics. The most important similarity is the object of research, which is the plant world; of course, in the case of ethnolinguistics, the area of interest extends to the entire traditional worldview, and plants constitute only one of its fragments.

Furthermore, ethnobotany is interested in relationships holding between the plant and human worlds (Faulks 1958; Łuczaj 2013) and the reasons for the changing context in which people and plants interact (Alcorn 1995); relations and causes, the richness and complexity of which are perfectly demonstrated in the linguistic and cultural worldviews of plants, reconstructed with the use of the cognitive definition. 
Table 1. Selected semantic subcategories most frequently repeated in plant descriptions, along with their simplified characteristics

complexes and collections

oppositions

origin

appearance and properties

flowering and harvesting time

cultivation and care

location

resident

blessing
In this facet the authors of dictionary entries show which things and phenomena coexist with the described plant, performing a common function, e.g. in folk songs, the carnation (Dianthus), as a symbol of virginity, coexists with other flowers/herb from a girl's garland, i.e. with chamomile (Matricaria), rosemary (Rosmarinus), myrtle (Myrtus) and rose (Rosa) (Neppop-Ajdačić 2019).

This semantic subcategory shows the oppositions which the described plant builds with other plants and which feature becomes the basis of the opposition, e.g. in a puzzle, the pleasant smell of violet (Viola) is contrasted with the unpleasant smell of onion (Allium cepa), cf. Smaruj Żyda fiołkami, a jego i tak czuć będzie cebulą [Smear the Jew with violets, and he will still smell of onions] (Bielak 2019).

This subcategory registers information about where the plant came from or how it was made, e.g. according to a legend, pea (Pisum) was made out of tears shed by Our Lady under the cross, and for this reason it is called łzy Matki Boskiej [Our Lady's tears] (Bartmiński, Prorok 2018); while pansy (Viola tricolor) is a result of the transformation from a sister and a brother, bound by incestuous love (Szadura 2019).

This segment of the definition reconstructs the appearance of the analysed plant (size, colour of flowers or fruit) and its properties (e.g. smell); for example, a fragment of the definition of cucumber (Cucumis sativus): it is elongated, green or yellow, smooth on the top or covered with characteristic rough projections, hard and crunchy, watery, has a fresh smell, is tasty (Prorok 2018a).

In this facet, readers will find information on the plant's flowering time and harvesting period; in the case of some plants, the time of ripening and harvesting was so important to users that it was reflected already at the level of names, e.g. the variety of potatoes (Solanum tuberosu) ripening around St. John's Day (24 June) is called świętojanki [St. John's] in the Lublin region (Bartmiński, Bielak 2018).

This segment of the definition gives information on the cultivation of the described plant, e.g. information on sowing, planting out, weeding, ear thing up or harvesting cabbage (Brassica oleracea) (Prorok 2018b). For some plants, cultivation and care are the responsibility of certain individuals, e.g. growing roses (Rosa) is an activity performed by a maiden who plants them as a sign of being ready for love (Niebrzegowska-Bartmińska 2019).

This semantic category indicates the place where the described plant occurs (grows), e.g. the lavender (Lavandula) usually grows in the garden, where it is looked after by girls (Prorok 2019a).

This facet compiles information on who resides/stays in the described plant, e.g. in the folklore, numerous demonic beings, such as field and cereal demons, poludnitsas live in the rye (Secale) (Bartmiński, Kaczan 2017); or in folklore love songs, the field where the cabbage grows (Brassica oleracea) is a meeting place for lovers; in Kashubia, przenśc bez kapustã means 'to get pregnant' (Prorok 2018b).

This semantic category provides information on when and under what circumstances the described plant is blessed, e.g. the onion (Allium cepa), treated as a herb, was blessed with other plants on the Day of Epiphany ( 6 January) and on the Day of Our Lady of Herbs (15 August) (Bartmiński, Łaszkiewicz 2018). 
practical applications

ritualistic applications

magical applications

medicinal applications

prophecies + fortune-telling

equivalents

symbolism
This facet contains information on all the practical uses of the given plant, not only as food - whether raw or processed - or as a raw material for manufacturing domestic appliances or household items. Practical applications may include colouring Easter eggs in onion extract (Allium cepa) (Bartmiński, Łaszkiewicz 2018) or young rye stalks (Secale) (Bartmiński, Kaczan 2017), kneeling on peas (Pisum) - formerly used as a painful punishment for children (Bartmiński, Prorok 2018) or making children's toys from carrots (Daucus carota) (Prorok 2018c).

This segment of the definition contains information on the use of the described plant in annual rituals (e.g. during Christmas, Easter) and family rituals (christening, wedding and funeral). e.g. straw as the material from which the ritual puppets were made, such as bear or Marzanna (Bartmiński, Bielak 2017) or the hemp (Cannabis sativa) which was used for coffin clothes for the deceased (Niebrzegowska-Bartmińska 2018).

Readers will find here information on the magical use of the described plant (protective, love, household magic), e.g. incensing a house with the cornflower (Centaurea) should protect it against lightning, while incensing cows protected them against witches (Piekarczyk, Szadura 2019); feeding peas (Pisum) to animals, inter alia, to hens - to lay more eggs, to the rooster - to be vigorous and crow better, or to pigeons - so that they do not leave their pigeon loft (Bartmiński, Prorok 2018).

This facet includes information on the use of the defined plant in folk human or veterinary medicine, e.g. the use of peas (Pisum) in the treatment of skin lesions resembling their shape, i.e. warts, lichen, callouses, or washing ulcerated cow's udders with pea decoction (Bartmiński, Prorok 2018). The dictionary registers both medically justified practices and magical treatments, e.g. the transfer of a disease to the plant.

These facets often appear together as both are linked to the ways people use the described plant to predict the future. Fortune-telling differs from prophecies in that the former requires a certain action on the part of the human; for example, when a girl, in order to find out how her beloved boy feels about her, takes a daisy (Bellis) and, peeling off its petals, repeats the formula: Kocha, nie kocha... [Loves, doesn't love...] (Kaczan 2019). In the case of a prophecy, the observation of the plant itself (e.g. the abundance of fruit on the plant) allows to deduce about the changes taking place in the world, e.g. a large amount of fruit on the cherry tree (Cerasus) heralds good harvest of potatoes (Solanum tuberosum) (Bartmiński, Bielak 2018).

When describing plants, the author of dictionary entries look for their "cultural equivalents", i.e. objects that appear in the same functions, e.g. the onion (Allium cepa) is interchangeable with the garlic (Allium) as the Jews' favourite vegetable (Bartmiński, Łaszkiewicz 2018).

This facet completes the explication, in a way summing up the definition of the plant, because the symbolism of plants can be extracted in various ways, e.g. through the analysis of the etymology or textual equivalents, or it can result from genological conventions (Niebrzegowska-Bartmińska 2013). We may deal with a simple symbol, e.g. a rose (Rosa) as a general symbol of beauty or maiden/woman's beauty (NiebrzegowskaBartmińska 2019), or with a complex symbol, a symbolic sequence, e.g. the image of the hops (Humulus lupulus) in love songs where it climbs up the pole, which symbolically stands for a love act (Bartmiński, Hrycyna 2018).
Ethnolinguistics and ethnobotany, similarly to ethnomethodologies (ethnohistory, ethnozoology, ethnoastronomy or ethnomedicine), focus on the study of a colloquial, folk way of thinking. As J. Bartmiński rightly points out, in the name of each of these disciplines the element ethno- is understood subjectively, it primarily refers to a specific community as a creator and carrier of a discipline of knowledge, a cultural order, certain forms of expression. Appropriate scientific disciplines perform 
a "subjective reconstruction", they want to look at the world through the eyes of a member of a given community, to recreate his or her point of view. It is only in the background (metaground) that this colloquial conceptualisation becomes an object of interest together with the conceptualising subject, the conceptualiser (Bartmiński 2008).

Ethnobotany studies folk knowledge about plants and considers the point of view and perspectives of the local population as crucial (Alexiades 2018). The emic perspective, i.e. the study of culture from the perspective of its users, is adopted particularly by ethnobotany understood as ethnobiology, interested in the way people from a particular region designate, categorise, classify, perceive and use their plants. In a similar vein, ethnolinguistics is interested in the subjective reconstruction of elements of the traditional worldview - not so much what $X$ means, as in the answer to the question how people (living in a particular territory, i.e. the whole ethnically Polish area) understand $X$.

Finally, both disciplines are linked by a special treatment of language, which - as it turns out - is natural not only for linguists, who - while constructing plant descriptions - use hard "linguistic evidence" allowing them to verify many of the hypotheses made, but also for ethnobotanists, who in their research often prioritise aspects of knowledge encoded in language (Alexiades 2018).

What is thus the difference between the representatives of both disciplines? Ethnolinguists are primarily linguists - they explore the essence of the language which is used to describe plants. In their descriptions they do not only recall the texts of verbal folklore, especially the texts of folk songs, but - aware of the metaphorical language of images, parallels and symbols - they try to decode them and write down the additional meanings associated with plants (with full awareness that the formulation of symbolic meanings always remains a hypothesis).

Modern ethnobotany emerged in the mid-19th century at the borderline of ethnology, archaeology and botany, and developed further over the next decades. It drew insights - to a different degree - from the achievements of natural and social sciences: agronomy, ecology, evolutionary biology, pharmacology, geography, history and linguistics, archaeology, ethnology and anthropology, becoming a multidisciplinary field of research (Alexiades 2018). Nevertheless, the pioneers of ethnobotanic research were naturalists by education, and contemporary ethnobotanic research is still undertaken mainly by botanical institutions (Łuczaj 2013).
Meanwhile, the review of ethnobotanical studies and the work in a team responsible for the development of SSiSL leads to the conclusion that ethnobotany is a part of ethnolinguistics understood as a subfield of linguistics, aimed at the subjective reconstruction of the worldview entrenched in language and culture. Going further along this path, it could be claimed that other ethnosciences also have many points in common with ethnolinguistic practiced in Lublin, e.g. elements of ethnomedicine appear in the facet related to the application or use of the elements of cosmos and plants in folk medicine, they also appear in the reconstructed definitions of animals. Ethnomedical research into health, including beliefs, knowledge and practices of a specific cultural group, is in line with the work of Marzena Marczewska (2012), devoted to linguistic and cultural images of selected diseases. The common point between ethnozoology and ethnolinguistics is folk knowledge about animals as well as the relations between humans and animals, which will be described in the third volume of SSiSL, dedicated to animals. At the meeting point between the world of animals and the world of plants there are ethnolinguistic studies on the names of animals in plant names; cf., inter alia, J. Waniakowa (2015) or V. Kolosova et al. (2017).

This should make it clear to scholars that reaching for the studies from other scientific fields will allow them to see their research in a different light, from a different perspective.

Translated by Rafał Augustyn

(Maria Curie-Skłodowska University in Lublin)

\section{Declarations}

List of abbreviations: Not applicable

Ethical approval and consent to participate: Not applicable

Consent for publication: Not applicable

Conflict of interests: The authors declare that they have no conflict of interests.

Funding: Scientific work financed by the Polish Ministry of Science and Higher Education under the "National Programme for the Development of Humanities" for the years 2015-2020. Project title: "The world of plants in the Polish folk and common language (trees, grains, flowers, herbs, mushrooms etc.). Ethnolinguistic Dictionary". Principal investigator: Prof. Jerzy Bartmiński.

Authors' contributions: Not applicable

Acknowledgements: Not applicable

\section{Literature Cited}

Alcorn JB. 1995. The Scope and Airns of Ethnobotany in a Developing World. Ethnobotany Evolution of the Discipline. Edited by RE Schultes, S von Reis. Chapman, Hall, London, U.K., Pp. 23-39. 
Alexiades MN. 2018. Ethnobotany. The International Encyclopedia of Anthropology. Edited by $\mathrm{H}$ Callan. Wiley.

Bächtold-Stäubli $\quad \mathrm{H} \quad$ (ed). 1927-1941. Handwörterbuch des deutschen Aberglaubens. Vol. 1-10. Walter de Gruyter, Co, Berlin und Leipzig, Germany.

Bańkowski A. 2000. Etymologiczny słownik języka polskiego. Vol. 1-2. Wydawnictwo Naukowe PWN, Warszawa, Poland.

Bartmiński J. 1980. Słownik ludowych stereotypów językowych. Zeszyt próbny. Wydawnictwa Uniwersytetu Wrocławskiego, Wrocław, Poland.

Bartmiński J. 1988. Definicja kognitywna jako narzędzie opisu konotacji. Konotacja. Edited by $\mathrm{J}$ Bartmiński. Wydawnictwo Uniwersytetu Marii CurieSkłodowskiej, Lublin, Poland, Pp. 169-183.

Bartmiński J. 1990. Punkt widzenia, perspektywa, językowy obraz świata. Językowy obraz świata. Edited by J Batrmiński. Wydawnictwo Uniwersytetu Marii Curie-Skłodowskiej, Lublin, Poland, Pp. 109127.

Bartmiński J. 1996. O słowniku stereotypów i symboli ludowych. Słownik stereotypów i symboli ludowych. Vol. 1: Kosmos, Part 1: Niebo, światła niebieskie, ogień, kamienie. Overall concept and chief ed: J Bartmiński, vice-ed: S Niebrzegowska-Bartmińska. Wydawnictwo Uniwersytetu Marii CurieSkłodowskiej, Lublin, Poland, Pp. 9-25.

Bartmiński J. 2002. Etnolingwistyka. Wielka encyklopedia PWN. Vol. 8. Edited by J. Wojnowski. Wydawnictwo Naukowe PWN, Warszawa, Poland, Pp. 380-381.

Bartmiński J. 2005. Jazykovaja kartina mira. Očerki po ètnolingvistike, Indrik, Moscow, Russia.

Bartmiński J. 2006. Językowe podstawy obrazu świata. Wydawnictwo Uniwersytetu Marii CurieSkłodowskiej, Lublin, Poland.

Bartmiński J. 2007. Stereotypy mieszkają w języku. Studia etnolingwistyczne. Wydawnictwo Uniwersytetu Marii Curie-Skłodowskiej, Lublin, Poland.

Bartmiński J. 2008. Etnolingwistyka, lingwistyka kulturowa, lingwistyka antropologiczna? Język a Kultura 20: 15-33.

Bartmiński J. 2009. Aspects of Cognitive Ethnolinguistics. Equinox Publishing Ltd, London and Oakville, U.K.
Bartmiński J. 2011a. Jezik - slika - svet. Etnolingvisticke studije. SlovoSlavia, Beograd, Serbia.

Bartmiński J. (ed). 2011b. Polska pieśń i muzyka ludowa. Źródła i materiały. Vol. 4: Lubelskie; Part 1: Pieśni i obrzędy doroczne; Part 2: Pieśni i obrzędy rodzinne. Instytut Sztuki PAN, Lublin, Poland.

Bartmiński J. 2016. Jazyk v kontextu kultury. Dvanáct statí z lublinské kognitivní etnolingvistiky, Karolinum, Prague, Czech Republic.

Bartmiński J. 2017. Od redaktora. Słownik stereotypów i symboli ludowych. Vol. 2: Rośliny, Part 1: Zboża. Overall concept and chief ed: J Bartmiński, vice-ed: S Niebrzegowska-Bartmińska. Wydawnictwo Uniwersytetu Marii CurieSkłodowskiej, Lublin, Poland, Pp. 7-14.

Bartmiński J, Bielak A. 2017. Słoma. Słownik stereotypów i symboli ludowych. Vol. 2: Rośliny, Part: 1: Zboża. Overall concept and chief ed: J Bartmiński, vice-ed: S Niebrzegowska-Bartmińska. Wydawnictwo Uniwersytetu Marii CurieSkłodowskiej, Lublin, Poland, Pp. 158-187.

Bartmiński J, Bielak A. 2018. Kartofel (Solanum tuberosum). Słownik stereotypów i symboli ludowych. Vol. 2: Rośliny, Part: 2: Warzywa, przyprawy, rośliny przemysłowe. Overall concept and chief ed: J Bartmiński, vice-ed: S Niebrzegowska-Bartmińska. Wydawnictwo Uniwersytetu Marii Curie-Skłodowskiej, Lublin, Poland, Pp. 149-172.

Bartmiński J, Hrycyna E. 2018. Chmiel (Humulus lupulus). Słownik stereotypów i symboli ludowych. Vol. 2: Rośliny, Part: 2: Warzywa, przyprawy, rośliny przemysłowe. Overall concept and chief ed: J Bartmiński, vice-ed: S Niebrzegowska-Bartmińska. Wydawnictwo Uniwersytetu Marii CurieSkłodowskiej, Lublin, Poland, Pp. 493-502.

Bartmiński J, Kaczan A. 2017. Żyto (Secale). Słownik stereotypów i symboli ludowych. Vol. 2: Rośliny, Part: 1: Zboża. Overall concept and chief ed: J Bartmiński, vice-ed: S NiebrzegowskaBartmińska. Wydawnictwo Uniwersytetu Marii CurieSkłodowskiej, Lublin, Poland, Pp. 199-231.

Bartmiński J, Łaszkiewicz M. 2018. Cebula (Allium серa). Słownik stereotypów i symboli ludowych. Vol. 2: Rośliny, Part: 2: Warzywa, przyprawy, rośliny przemysłowe. Overall concept and chief ed: J Bartmiński, vice-ed: S Niebrzegowska-Bartmińska. Wydawnictwo Uniwersytetu Marii CurieSkłodowskiej, Lublin, Poland, Pp. 295-311.

Bartmiński J, Niebrzegowska S. 1998. Profile a podmiotowa interpretacja świata. Profilowanie w języku i w tekście. Edited by J Bartmiński, R 
Tokarski. Wydawnictwo Uniwersytetu Marii CurieSkłodowskiej, Lublin, Poland, Pp. 211-223.

Bartmiński J, Niebrzegowska-Bartmińska S. 2013. Czy grzyb jest rośliną, czyli co znajdzie się w polu Rośliny w II tomie „Słownika stereotypów i symboli ludowych". Sapientia Ars Vivendi. Księga Jubileuszowa ofiarowana Profesor Annie Dąbrowskiej. Edited by A Burzyńska-Kamieniecka, A Libura. Oficyna Wydawnicza „Atut” -Wrocławskie Wydawnictwo Oświatowe, Wrocła, Poland, Pp. 4164.

Bartmiński J, Prorok K. 2018. Groch (Pisum). Słownik stereotypów i symboli ludowych. Vol. 2: Rośliny, Part: 2:Warzywa, przyprawy, rośliny przemysłowe. Overall concept and chief ed: J Bartmiński, vice-ed: S Niebrzegowska-Bartmińska. Wydawnictwo Uniwersytetu Marii CurieSkłodowskiej, Lublin, Poland, Pp. 9-43.

Bielak A. 2019. Fiołek (Viola). Słownik stereotypów i symboli ludowych. Vol. 2: Rośliny, Part: 3: Kwiaty. Overall concept and chief ed: J Bartmiński, vice-ed: S Niebrzegowska-Bartmińska. Wydawnictwo Uniwersytetu Marii Curie-Skłodowskiej, Lublin, Poland, Pp. 87-96.

Burszta J. (ed). 1967. Kultura ludowa Wielkopolski. Vol. 3. Wydawnictwo Poznańskie, Poznań, Poland.

Bystroń JS. (ed). 1927. Pieśni ludowe z polskiego Śląska; Part 1: Pieśni balladowe. Polska Akademja Umiejętności, Kraków, Poland.

Cercha S. 1904. Poglądy ludu na przyrodę. Łopuszna nad Dunajcem. Wisła 18:811-812.

Ciszewski S. 1886. Lud rolniczo-górniczy z okolic Sławkowa w powiecie Olkuskim (Part 1). Zbiór Wiadomości do Antropologii Krajowej 10:187-336.

Dafni A. 2016. Myrtle (Myrtus communis) as a Ritual Plant in the Holy Land - a Comparative Study in Relation to Ancient Traditions. Economic Botany $X X: 1-13$.

Dafni A, Petanidou T, Vallianatou I, Kozhuharova E, Blanché C, Pacini E, Peyman M, Stevanovic ZD, Franchi GG, Benítez G. 2019. Myrtle, Basil, Rosemary, and Three-Lobed Sage as Ritual Plants in the Monotheistic Religions: an HistoricalEthnobotanical Comparison. Economic Botany.

Dejna K. 1978. Słownictwo ludowe z terenów województwa kieleckiego i łódzkiego. Rozprawy Komisji Językowej. Wydawnictwo Łódzkiego Towarzystwa Naukowego; 24:149-274.

Dekowski JP. 1978. Z badań nad problematyką wesela opoczyńskiego. Łódzkie Studia Etnograficzne 23:5-82.
Dekowski JP. 1988. Zwyczaje rodzinne i doroczne kaliszan w świetle konkursu folklorystycznego. Łódzkie Studia Etnograficzne 28:45-62.

Drabik W. 1990. Cztery pory życia (o współzależności obrzędów dorocznych i rodzinnych). Polska Sztuka Ludowa 1:15-30.

Dubisz S. 1977. Nazwy roślin w gwarach ostródzkowarmińsko-mazurskich. Zakład Narodowy im. Ossolińskich, Wrocław, Poland.

Dygacz A. 1987. Pieśni ludowe miasta Katowic. Źródła i dokumentacja. Katowickie Towarzystwo Społeczno-Kulturalne, Katowice, Poland.

Faulks PL. 1958. An Introduction to Ethnobotany. Moredale Publiations Limited, London, U.K.

Fischer A. 1921. Zwyczaje pogrzebowe ludu polskiego. Zakład Narodowy im. Ossolińskich, Lwów, Ukraine.

Forstner D. 1990. Świat symboliki chrześcijańskiej. Instytut Wydawniczy Pax, Warszawa, Poland.

Gaj-Piotrowski W. 1967. Kultura społeczna ludu z okolic Rozwadowa. Polskie Towarzystwo Ludoznawcze, Wrocław, Poland.

Gajek J. 1946. Polski atlas etnograficzny. Lud 36:408-412.

Gajek J. (ed). 1974. Polski Atlas Etnograficzny. Zeszyt V. Polska Akademia Nauk, Instytut Historii Kultury Materialnej, Warszawa, Poland.

Gajek J. (ed). 1981. Polski Atlas Etnograficzny. Zeszyt VI. Polska Akademia Nauk, Instytut Historii Kultury Materialnej, Warszawa, Poland.

Gerlich H. 1984. Narodziny, zaślubiny, śmierć: zwyczaje i obrzędy w katowickich rodzinach górniczych. Śląski Instytut Naukowy, Katowice, Poland.

Głaz A. 2013. Prostowanie zwierciadła. Przyczynek do (jeszcze?) niezaistniałej dyskusji nt. kondycji lubelskiej etnolingwistyki. Biuletyn PTJ LXIX:139151.

Grochowski M. 1993. Konwencje semantyczne a definiowanie wyrażeń językowych, Zakład Semiotyki Logicznej Uniwersytetu Warszawskiego „Znak Język - Rzeczywistość”: Polskie Towarzystwo Semiotyczne, Warszawa, Poland.

Harshberger JW. 1896. The purposes of ethnobotany. Botanical Gazette 21:146-154.

Henslowa M. 1962. Rośliny dziko rosnące w kulturze ludu polskiego (Chenopodium, Atriplex, Urtica, Rumex, Sambucus). Polskie Towarzystwo Ludoznawcze, Wrocław, Poland. 
Hrycyna E. 2019. Ruta (Ruta graveolens). Słownik stereotypów i symboli ludowych. Vol. 2: Rośliny, Part: 4: Zioła. Overall concept and chief ed: J Bartmiński, vice-ed: S Niebrzegowska-Bartmińska. Wydawnictwo Uniwersytetu Marii CurieSkłodowskiej, Lublin, Poland, Pp. 356-375.

Janicka-Krzywda U. 2001. Mirtowy wianek i nie tylko. Kwiaty 4:13.

Kaczan A. 2019. Stokrotka (Bellis). Słownik stereotypów i symboli ludowych. Vol. 2: Rośliny, Part: 3: Kwiaty. Overall concept and chief ed: J Bartmiński, vice-ed: S Niebrzegowska-Bartmińska. Wydawnictwo Uniwersytetu Marii CurieSkłodowskiej, Lublin, Poland, Pp. 243-249.

Kantor J. 1907. Czarny Dunajec. Monografia etnograficzna. Materiały AntropologicznoArcheologiczne i Etnograficzne 9: 17-229.

Karłowicz J. 1900-1911. Słownik gwar polskich. Vol. 1-6. Nakładem Akademii Umiejętności, Kraków, Poland.

Karłowicz J, Kryński A, Niedźwiedzki W (ed). 19521953. Słownik języka polskiego. Vol. 1-8. Państwowy Instytut Wydawniczy, Warszawa, Poland.

Karwicka T. 1979. Kultura ludowa Ziemi Dobrzyńskiej. Państwowe Wydawnictwo Naukowe, Warszawa, Poland.

Kawalec. 1929. Zwyczaje ludu polskiego na Śląsku w okresie świąt Bożego Narodzenia. Zaranie Śląskie. Kwartalnik Literacki 5:236-242.

Kąś J. 2011. Słownik gwary orawskiej. Vol. 1-2. Księgarnia Akademicka, Kraków, Poland.

Kąś J. 2015-2018. Ilustrowany leksykon gwary i kultury podhalańskiej. Vol. 1-6. Bukowińskie Centrum Kultury „Dom Ludowy”, Małopolskie Centrum Kultury Sokół, Bukowina Tatrzańska, Poland.

Kielak O. [forthcoming]. Mirt (Myrtus). Słownik stereotypów i symboli ludowych. Vol. 2: Rośliny, Part: 6: Krzewy i krzewinki. Overall concept and chief ed: J Bartmiński, vice-ed: S NiebrzegowskaBartmińska. Wydawnictwo Uniwersytetu Marii CurieSkłodowskiej, Lublin, Poland.

Klepacki P. 2007. Etnobotanika w Polsce przeszłość i teraźniejszość. Analecta 16 (1-2):191245.

Knoop O. 1895. Podania i opowiadania z W. Ks. Poznańskiego [Part 4]. Wisła 9:470-513.

Kolberg O. 1876/1963. Dzieła wszystkie. Vol. 10: W. Ks. Poznańskie; Part 2. Polskie Wydawnictwo
Muzyczne, Ludowa Spółdzielnia Wydawnicza, Kraków-Warszawa, Poland [original 1876].

Kolberg O. 1883/1962. Dzieła wszystkie. Vol. 16: Lubelskie; Part 1. Polskie Wydawnictwo Muzyczne, Ludowa Spółdzielnia Wydawnicza, KrakówWarszawa, Poland [orginal 1883].

Kolberg O. 1969. Dzieła wszystkie. Vol. 41: Mazowsze; Part 6. Edited by M Tarko. Polskie Wydawnictwo Muzyczne, Ludowa Spółdzielnia Wydawnicza, Kraków-Warszawa, Poland.

Kolosova VB, Svanberg I, Kalle R, Strecker L, Özkan AMG, Pieroni A, Cianfaglione K, Molnár Z, Papp N, Łuczaj Ł, Dimitrova D, Šeškauskaitè D, Roper J, Hajdari A, Sõukand R. 2017. The bear in Eurasian plant names: motivations and models. Journal of Ethnobiology and Ethnomedicine 13:14.

Kopaliński W. 1985. Słownik mitów i tradycji kultury. Państwowy Instytut Wydawniczy, Warszawa, Poland.

Kopczyńska-Jaworska B. 1989. Zmiany wzorów kultury chłopskiej w miejskim środowisku robotniczym: zawarcie małżeństwa i obrzędowość weselna w Łodzi i Żyrardowie. Łódzkie Studia Etnograficzne 29:51-65.

Kowalska-Lewicka A. 1964. Etnobotanika. Etnografia Polska 8:207-214.

Kowalski P. 1998. Leksykon znaki świata. Omen, przesąd, znaczenie. Wydawnictwa Naukowe PWN, Warszawa-Wrocław, Poland.

Köhler P. 1993. Ankieta Józefa Rostafińskiego z 1883 roku dotycząca ludowego nazewnictwa i użytkowania roślin w Polsce. Analecta - Studia i Materiały z Dziejów Nauki II 2 (4): 7-119.

Köhler P. 2014. An Involuntary Ethnobotanist? Józef Rostafiński (1850-1928) and his research in Poland. Pioneers in European Ethnobiology. Edited by I Svanberg, Ł Łuczaj. Uppsala University, Uppsala, Sweden, Pp. 149-179.

Köhler P. 2018. Etnobotanika Podhala na podstawie ankiety Józefa Rostafińskiego (1850-1928) z 1883 r. Etnobiologia Polska 8:39-98.

Kujawska M, Klepacki, Łuczaj Ł. 2017. Fischer's Plants in folk beliefs and customs: a previously unknown contribution to the ethnobotany of the Polish-Lithuanian-Belarusian borderland. Journal of Ethnobiology and Ethnomedicine 13:20.

Kujawska M, Łuczaj Ł, Sosnowska J, Klepacki P. 2016. Rośliny w wierzeniach i zwyczajach ludowych. Słownik Adama Fischera. Polskie Towarzystwo Ludoznawcze, Wrocław, Poland. 
Kujawska M, Łuczaj Ł, Typek J. 2015. Fischer's Lexicon of Slavic beliefs and customs: a previously unknown contribution to the ethnobotany of Ukraine and Poland. Journal of Ethnobiology and Ethnomedicine 11: 85.

Libera Z, Paluch A. 1993. Lasowiacki zielnik. Biblioteka Publiczna Miasta i Gminy Kolbuszowa, Kolbuszowa, Poland.

Lipiński A. 1965. Pozostałości kultury tradycyjnej w łódzkich rodzinach robotniczych. Łódzkie Studia Etnograficzne 7:5-39.

Łęga W. 1933. Ziemia Malborska. Kultura ludowa. Kasa im. Mianowskiego, Instytut Popierania Nauki, Toruń-Warszawa, Poland.

Łozowski P. 1999. Panchronia, czyli językoznawstwo bez synchronii. Przeszłość w językowym obrazie świata. Edited by A Pajdzińska, P Krzyżanowski. Wydawnictwo Uniwersytetu Marii Curie-Skłodowskiej, Lublin, Poland, Pp. 25-50.

Łuczaj Ł. 2011. Herbal bouquets blessed on Assumption Day in south-eastern Poland: freelisting versus photographic inventory. Ethnobotany Research and Applications 9:1-25.

Łuczaj Ł. 2013. Etnobotanika w Polsce u progu XXI wieku. Wiadomości Botaniczne 57:9-15.

Łuczaj Ł. 2014. The Engineer of Ethnobotanical Cartography. Polish ethnographer Józef Gajek (1907-1987) and his contribution to our science. Pioneers in European Ethnobiology. Edited by I Svanberg, Ł Łuczaj. Uppsala University, Uppsala, Sweden, Pp. 273-282.

Łuczaj Ł, Köhler P. 2011. Liście i inne zielone części dziko rosnących roślin w pożywieniu mieszkańców ziem polskich na podstawie ankiet Józefa Rostafińskiego (XIX w.) i Józefa Gajka (XX w.). Przegląd Historyczny 102 (4):733-770.

Marczewska M. 2012. Ja cię zamawiam, ja cię wypędzam... Choroba. Studium językowo-kulturowe. Instytut Filologii Polskiej UJK, Kielce, Poland.

Mayenowa MR (ed), Pepłowski F (vice-ed). 1982. Słownik polszczyzny XVI wieku. Vol. 14. Zakład Narodowy im. Ossolińskich, Wrocław-WarszawaKraków, Poland.

Nadmorski [Łęgowski J]. 1892. Kaszuby i Kociewie. Język, zwyczaje, przesądy, podania, zagadki i pieśni ludowe w północnej części Prus Zachodnich. Czcionkami Drukarni Dziennika Poznańskiego, Poznań, Poland.

Neppop-Ajdačić L. 2019. Goździk (Dianthus). Słownik stereotypów i symboli ludowych. Vol. 2: Rośliny, Part: 3: Kwiaty. Overall concept and chief ed: J Bartmiński, vice-ed: S NiebrzegowskaBartmińska. Wydawnictwo Uniwersytetu Marii CurieSkłodowskiej, Lublin, Poland, Pp. 99-108.

Niebrzegowska S. 1996. Polski sennik ludowy. Wydawnictwo Uniwersytetu Marii CurieSkłodowskiej, Lublin, Poland.

Niebrzegowska S. 2000. Przestrach od przestrachu. Rośliny w ludowych przekazach ustnych. Wydawnictwo Uniwersytetu Marii CurieSkłodowskiej, Lublin, Poland.

Niebrzegowska-Bartmińska S. 2013. Ustalanie znaczeń symbolicznych w słowniku etnolingwistycznym. LingVaria 1(15):127-144.

Niebrzegowska-Bartmińska S. 2014. Od separacyjnego do holistycznego opisu językowego obrazu świata. Na marginesie dyskusji nad kształtem artykułów w „Leksykonie aksjologicznym Słowian i ich sąsiadów". Wartości Słowian i ich sąsiadów. Vol. 3: Problemy eksplikowania i profilowania pojęć. Edited by I Bielińska-Gardziel, S NiebrzegowskaBartmińska, J Szadura. Wydawnictwo Uniwersytetu Marii Curie-Skłodowskiej, Lublin, Poland, Pp. 71102.

Niebrzegowska-Bartmińska S. 2018. Konopie (Cannabis sativa). Słownik stereotypów i symboli ludowych. Vol. 2: Rośliny, Part: 2: Warzywa, przyprawy, rośliny przemysłowe. Overall concept and chief ed: J Bartmiński, vice-ed: S Niebrzegowska-Bartmińska. Wydawnictwo Uniwersytetu Marii Curie-Skłodowskiej, Lublin, Poland, Pp. 425-454.

Niebrzegowska-Bartmińska S. 2019. Róża (Rosa). Słownik stereotypów i symboli ludowych. Vol. 2: Rośliny, Part: 3: Kwiaty. Overall concept and chief ed: J Bartmiński, vice-ed: S NiebrzegowskaBartmińska. Wydawnictwo Uniwersytetu Marii CurieSkłodowskiej, Lublin, Poland, Pp. 203-238.

Paluch A. 1985 . Miejsce roślin w praktykach i zwyczajach związanych ze śmiercią człowieka na wsi polskiej. Etnobotanika. Materiały । Ogólnopolskiego Seminarium Etnobotanicznego, Kolbuszowa 19-20 VII 1980 r. Edited by A Paluch. Wydawnictwo Uniwersytetu Wrocławskiego, Kolbuszowa, Poland.

Paluch A. 1988. Świat roślin w tradycyjnych praktykach leczniczych wsi polskiej. Wydawnictwo Uniwersytetu Wrocławskiego, Wrocław, Poland.

Pelcowa H. 2017. Słownik gwar Lubelszczyzny. Vol. 5: Świat roślin. Wydawnictwo Uniwersytetu Marii Curie-Skłodowskiej, Lublin, Poland.

Piekarczyk D, Szadura J. 2019. Chaber (Centaurea). Słownik stereotypów i symboli ludowych. Vol. 2: 
Rośliny, Part: 3: Kwiaty. Overall concept and chief ed: J Bartmiński, vice-ed: S NiebrzegowskaBartmińska. Wydawnictwo Uniwersytetu Marii CurieSkłodowskiej, Lublin, Poland, Pp. 71-84.

Płatek P. (ed). 1976. Albośmy to jacy tacy. Zbiór pieśni Krakowiaków wschodnich i zachodnich. Krajowa Agencja Wydawnicza, Kraków, Poland.

Podgórski A, Podgórska B. 2008. Słownik gwar śląskich: godómy po naszymu, czyli po śląsku. Wydawnictwo Kos, Katowice, Poland.

Pośpiech J. 1987. Zwyczaje i obrzędy doroczne na Śląsku. Instytut Śląski, Opole, Poland.

Prorok K. 2018a. Ogórek (Cucumis sativus). Słownik stereotypów i symboli ludowych. Vol. 2: Rośliny, Part: 2: Warzywa, przyprawy, rośliny przemysłowe. Overall concept and chief ed: J Bartmiński, vice-ed: S Niebrzegowska-Bartmińska. Wydawnictwo Uniwersytetu Marii Curie-Skłodowskiej, Lublin, Poland, Pp. 139-148.

Prorok K. 2018b. Kapusta (Brassica oleracea). Słownik stereotypów i symboli ludowych. Vol. 2: Rośliny, Part: 2: Warzywa, przyprawy, rośliny przemysłowe. Overall concept and chief ed: J Bartmiński, vice-ed: S Niebrzegowska-Bartmińska. Wydawnictwo Uniwersytetu Marii CurieSkłodowskiej, Lublin, Poland, Pp. 80-121.

Prorok K. 2018c. Marchew (Daucus carota). Słownik stereotypów i symboli ludowych. Vol. 2: Rośliny, Part: 2: Warzywa, przyprawy, rośliny przemysłowe. Overall concept and chief ed: J Bartmiński, vice-ed: S Niebrzegowska-Bartmińska. Wydawnictwo Uniwersytetu Marii Curie-Skłodowskiej, Lublin, Poland, Pp. 238-252.

Prorok K. 2019a. Lawenda (Lavandula). Słownik stereotypów i symboli ludowych. Vol. 2: Rośliny, Part: 3: Kwiaty. Overall concept and chief ed: J Bartmiński, vice-ed: S Niebrzegowska-Bartmińska. Wydawnictwo Uniwersytetu Marii CurieSkłodowskiej, Lublin, Poland, Pp. 123-130.

Prorok K. 2019b. Kaczeniec (Caltha palustris). Słownik stereotypów i symboli ludowych. Vol. 2: Rośliny, Part: 3: Kwiaty. Overall concept and chief ed: J Bartmiński, vice-ed: S NiebrzegowskaBartmińska. Wydawnictwo Uniwersytetu Marii CurieSkłodowskiej, Lublin, Poland, Pp. 110-113.

Pyla G. 2004. Prymicje jako obrzęd przejścia. Lud 88:79-90.

Reinfuss R. (ed). 1965. Nad rzeką Ropą. Zarys kultury ludowej powiatu gorlickiego. Wydawnictwo Literackie, Kraków, Poland.
Rogowska E. 1998. Kaszubskie nazwy roślin uprawnych. Wydawnictwo Uniwersytetu Gdańskiego, Gdańsk, Poland.

Rokossowska Z. 1889. O świecie roślinnym wyobrażenia, wierzenia i podania ludu ruskiego na Wołyniu we wsi Jurkowszczyzna. Zbiór Wiadomości do Antropologii Krajowej 13:163-199.

Rostafiński J. 1888. Burak i barszcz. Nazwa i rzecz. Ich pochodzenie i znaczenie w kolei czasów. Rozprawy i Sprawozdania Wydziału Filologicznego Akademii Umiejętności 8:314-339.

Rostafiński J. 1895. Zielnik czarodziejski to jest zbiór przesądów o roślinach. Zbiór Wiadomości do Antropologii Krajowej 18:1-191.

Rostafiński J. 1911. Ćwikła i buraki w Polsce. Sprawozdania z Czynności i Posiedzeń Akademii Umiejętności w Krakowie 16 (8):13.

Rostafiński J. 1916. O nazwach oraz użytkach ćwikły, buraków i barszczu. Nakładem Akademii Umiejętności, Kraków, Poland.

Sobierajski Z. 1960. Teksty gwarowe z Nowego Kramska w powiecie sulechowskim. Literatura Ludowa 4:38-43.

Steuer F. 1937. Narzecze baborowskie. Nakładem Polskiej Akademii Umiejętności, Kraków, Poland.

Sychta B. 1967-1976. Słownik gwar kaszubskich na tle kultury ludowej. Vol. 1-7. Zakład Narodowy im. Ossolińskich, Wrocław, Poland.

Svanberg I, Łuczaj Ł. 2014. Activity Contexts and Biocultural Domains. Pioneers in European Ethnobiology. Edited by I Svanberg, $Ł$ Łuczaj. Uppsala University, Uppsala, Sweden, Pp. 9-26.

Szadura J. 2019. Bratek (Viola tricolor). Słownik stereotypów i symboli ludowych. Vol. 2: Rośliny, Part: 3: Kwiaty. Overall concept and chief ed: J Bartmiński, vice-ed: S Niebrzegowska-Bartmińska. Wydawnictwo Uniwersytetu Marii CurieSkłodowskiej, Lublin, Poland, Pp. 62-70.

Szeląg F. 1934. Boży rok w zwyczajach i obrzędach ludu żywieckiego w okresie dorocznych świąt. Orli Lot 15:138-153.

Szulczewski JW. 1966. „Pieśni bez końca”. Zbiór tekstów folklorystyczno-etnograficznych. Łysiak W. (ed). PSO, Poznań, Poland.

Szymańska J. 1991. Podlaskie pieśni włóczebne. Etnolingwistyka 5:97-134.

Szymańska J. (ed). 2012. Polska pieśń i muzyka ludowa. Źródła i materiały. Vol. 5: Podlasie; Part 2: Teksty pieśni powszechnych. Instytut Sztuki PAN, Warszawa, Poland. 
Śmiełowski S. 1967. Kleklimanki. Opowieści ludowe ze Śląska Opolskiego. Śląsk, Katowice, Poland.

Świątkowska A. 1978. Zwyczaje i obrzędy rodzinne regionu łowickiego $\mathrm{w}$ procesie zmian ( $\mathrm{z}$ dokumentacji terenowej). Łódzkie Studia Etnograficzne 20:27-79.

Tabakowska E. 2001. Kognitywizm. Obrazki z polskiej sceny. Glossos. https://slaviccenters.duke.edu/sites/slaviccenters.du ke.edu/files/media_items_files/tabakowska.original. pdf. Accessed 10 Sept 2019.

Tabakowska E. 2013. A linguistic picture, image, or view of 'Polish Cognitive Studies'. The Linguistic Worldview. Ethnolinguistics, Cognition, and Culture. Edited by A Głaz, DS Danaher, P Łozowski. Walter de Gruyter GmbH, London, U.K., Pp. 321-338.

Toeppen M. 1892. Wierzenia mazurskie [Part 2]. Wisła 6:391-420.

Tołstoj NI. 1992. Język a kultura (Niektóre zagadnienia słowiańskiej etnolingwistyki). Etnolingwistyka 5:15-25.

Udziela S. 1890. Lud polski w powiecie Ropczyckim w Galicyi [Part 1]. Zbiór Wiadomości do Antropologii Krajowej 14:1-136.

Udziela S. 1994. Ziemia Biecka. Lud polski w powiatach gorlickim i grybowskim. Sądecka Oficyna Wydawnicza WOK, Nowy Sącz, Poland.

Waniakowa J. 2015. Nazwy zwierząt w nazwach roślin. Dialog pokoleń w języku potocznym, w języku wsi i miasta, w literaturze, w publicystyce, w tekstach kultury. Edited by E Wierzbicka-Piotrowska. Wydział Polonistyki Uniwersytetu Warszawskiego, Warszawa, Poland, Pp. 187-194.

Wronicz J (ed). 1995. Słownik gwarowy Śląska Cieszyńskiego. Towarzystwo Miłośników Wisły, Towarzystwo Miłośników Ustronia, Wisła-Ustroń, Poland.

Zborowski J. 1932. Ludoznawcze przyczynki z góralszczyzny. Lud 31:65-120.

Zinken J. 2009. The Ethnolinguistic School of Lublin and Anglo-American cognitive linguistics. Bartmiński J. Aspects of Cognitive Ethnolinguistics. Equinox Publishing Ltd, London and Oakville, U.K., Pp. 1-5.

\section{Field recording:}

Jasiennik Stary 1977. Field recording from Jasiennik Stary, Lubelskie Province, Biłgoraj District, 1977, deposited in the "Ethnolinguistic Archive" of Maria Curie-Skłodowska University in Lublin.
Niedźwiada 1977. Field recording from Niedźwiada, Lubelskie Province, Lubartów District, 1977, deposited in the "Ethnolinguistic Archive" of Maria Curie-Skłodowska University in Lublin.

Wietlin 1988. Field recording from Wietlin, Podkarpackie Province, Jarosław District, 1988, deposited in the "Ethnolinguistic Archive" of Maria Curie-Skłodowska University in Lublin. 